\title{
Microbiological Analysis of Abattoir Effluent Discharged into Eliozu River
}

\author{
CJ Ugboma ${ }^{1 *}$, FL Emmanuel ${ }^{1}$, GC Disegha ${ }^{1}$ and ET Godam ${ }^{2}$ \\ ${ }^{1}$ Department of Microbiology, Rivers State University, Nkpolu Oroworukwo, \\ PortHarcourt Rivers State, Nigeria \\ ${ }^{2}$ Department of Human Anatomy, Faculty of Basic Medical Sciences, Rivers State \\ University, Nkpolu Oroworukwo, PortHarcourt Rivers State, Nigeria \\ *Corresponding Author: CJ Ugboma, Department of Microbiology, Rivers State \\ University, Nkpolu Oroworukwo, PortHarcourt Rivers State, Nigeria.
}

Received: August 20, 2021

Published: October 22, 2021

(C) All rights are reserved by $\mathbf{C J}$ Ugboma., et al.

\begin{abstract}
Environmental issue is yet another dimension of the problems of the problems of development in Nigeria within the framework of comprehensive economic and social planning. Discharge of abattoir effluent and the microbiological effect on the environment, specifically bacteriological effects, are the topical issues focused on in this research. The effect of abattoir effluent on the quality of the water in Eliozu river, Rivers State has been studied. The bacteriological parameters, THB, TCC, TFC, TSSC and TVC were examined. Samples were collected in 3weeks from four points, three points (A,B,C) were collected from the Eliozu river, harboring the discharged abattoir effluent while point $\mathrm{D}$ was collected as control from another river without abattoir effluents. The bacteria species were isolated, identified using standard microbiological and biochemical techniques to assess the quality and extent of pollution through the discharge of wastes from the abattoir site into the river. Antibiogram was carried out using Kirby-Bauer disk diffusion method. THB had the highest CFU/ml in week 1 with $744 \times 10^{7} \mathrm{Cfu} / \mathrm{ml}$, TCC had the highest in week2 with $493 \times 10^{5} \mathrm{Cfu} / \mathrm{ml}$, TFC had the highest in week with $149 \mathrm{x}$ $10^{4} \mathrm{Cfu} / \mathrm{ml}$, and TSSC had the highest in week1 with $94.5 \times 10^{5} \mathrm{Cfu} / \mathrm{ml}$. The gram negative bacteria were both resistant and susceptible to the antibiotics used, few were intermediate. The gram positive bacteria were more susceptible to the antibiotics used, few were resistant or intermediate. The data from the results were subject to analysis of variance, no data was achieved from TVC, so it was excluded. All the parameters calculated, were all significant at both 5\% and 1\%. This implies that there is statistically significant variation between the samples taken weekly and indicates a high effect of pollution from the abattoir. The study has shown that the effluent is microbiologically hazardous to the health of the public that are in contact with the Eliozu River.
\end{abstract}

Keywords: Eliozu River; Parameters; Abattoir

\section{Introduction}

Abattoir as a word was coined out from a word of French, "Abattre" which literarily could be said to mean "bring down". Abattoir is also known as slaughter house where animals such as cattle, goats, and other animals are dressed, killed, and distributed for consumption.

Abattoir referred to as a slaughter place could be where different types of animals both domesticated and none domesticated 
are killed and processed for use. Abattoir or slaughter houses are largely industries where animal meat are slaughtered, processed and possibly packaged. Activities in abattoirs are geared to process the useful portions of slaughtered animal that will be of good use for humans $[1,2]$. Abattoir could also be said to be designated areas where animals are killed, processed for the purpose of meat.

In Nigeria abattoirs are one of the most important industries which could serve for different purposes namely processing meat, processing raw materials for manufacturing industries and source of livelihood. The different wastes derived from processing of meat in abattoir as well as animal are dumped into the water bodies which are generally used by humans for drinking, cooking and bathing.

Microorganisms such as bacteria derived from abattoir wastes can get into the different water columns reaching the sediment area, and when these sediments are agitated they send back the bacteria into the water column and thereby remain as a major threat to health $[3,4]$. Different pathogens are present in animal bodies and could also be deposited in animal wastes these include rotaviruses, hepatitis E virus, Salmonella spp., E. coli 0157: H7, Yersinia enterocolitica, Campylobacter spp., Cryptosporidium parvum, and Giardia lamblia (Sobsey., et al. 2002).

Mohammed and Musa [5] in their work were able to show that the non proper disposal of abattoir effluent could generate a load of distribution of pathogens to human which may cause major water borne diseases e.g. diarrhoea, pneumonia, typhoid, fever, asthma, respiratory and chest diseases etc. and studies have shown that Escherichia coli infection sources was due to uncooked beef which previously was contaminated in an abattoir with faeces containing the bacterium [6].

Potential health risks from waterborne pathogens can exist in water contaminated by abattoir effluents, runoff from feedlots, dairy farms, grazed pastures, fallow and sod amended with poultry litter, grassland treated with dairy manure, and sewage sludge treated land. Such contamination of water bodies from abattoir wastes could be a major source of environmental and public health hazards. Wastes from slaughterhouses/abattoirs are known to habour fat, grease, hair, feathers, flesh, manure, grit and undigested feed, blood, bones and process water which are typifications for high organic level $[4,7]$.
In Nigeria, water pollution (surface) is always attributed to surface runoff, industrial effluent, cold-room effluent, domestic waste and abattoir effluent. In this study, emphasis is placed on effluent generated from abattoir processes.

In the Southern part of Nigeria different pathogenic species of bacteria in abattoir effluent have been identified, these species among others include Staphylococcus sp., Streptococcus sp., depicting the unfriendly nature of untreated abattoir effluent dumped into the surrounding environment and hence threatening human health [8].

The main animal wastes are generated from killing; hide removal or, paunch handling, rendering, trimming, processing and cleanup operations of the animal. The wastes generated from slaughter house usually constitute blood, grease, inorganic and organic solids, salts and chemical added during processing operations. On the average, alot of the abattoirs in Nigeria are situated close to a stream, natural pond or river, like the one present in Eliozu River, Port Harcourt, Rivers state.

The Eliozu abattoir on daily basis produces several gallons of blood, and intestinal contents and tissues introducing them into the environment including the Eliozu River. On a visit to the Eliozu abattoir, during a quick survey around the abattoir, neither holding tank nor waste treatment system/facility was observed which is obviously an indication that effluent and other solid wastes generated from the abattoir are been dumped/discharged indiscriminately into the surrounding. The abattoir was said to have been in existence for years now, which implies that the water body has been receiving abattoir effluent for years.

\section{Study area}

The Eliozu River serves as the case study with respect to the abattoir effluent. Eliozu (4.8619352N, 7.0191502E), is a fast growing suburban in Obio/Akpor Local government area in Rivers State, Port Harcourt in Southern Nigeria. In Eliozu, activities including vehicle washing and bathing are possible through the river. People living within the vicinity draw water from the river and even swim. The river receives wastes from municipal dumps and from abattoir in the market sited along its course. Although, there are more than one abattoirs in Port Harcourt, Eliozu abattoir is implicated in this study due to its strategic location right by the course of the Eliozu 
market and river and also because at the time of the study, it was the only available abattoir which supplies about $65 \%$ of the meat for the local government area's residence and other nearby communities due to lock down in some parts of the local government area.

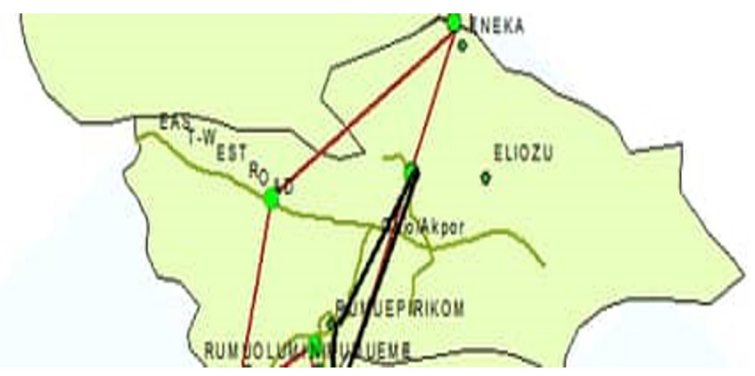

Figure 1: Map of Obio/Akpor showing Eliozu.

\section{Materials and Methods}

\section{Sample collection}

Samples for this study were collected three times in three months from Eliozu river.

The abattoir effluent samples were collected aseptically from four stations using sterile sample bottles.

- $\quad$ Station 1: Discharge point

- Station 2: Before the discharge point

- Station 3: Distance away from the discharge point

- Station 4: Control (another river without abattoir effluent).

All the samples were preserved and transported from the study area to the laboratory inside an airtight container with icepack.

\section{Media used}

- Nutrient Agar (N.A)

- MacConkey Agar (MCA)

- Salmonella Shigella Agar (SSA)

- Eosin Methylene Blue Agar (EMB).

\section{Results}

First sampling

\begin{tabular}{|l|c|c|}
\hline Samples & $\begin{array}{c}\text { Dilution1 } \\
\mathbf{1 0}^{-6}\end{array}$ & $\begin{array}{c}\text { Dilution2 } \\
\mathbf{1 0}^{-6}\end{array}$ \\
\hline A (discharge point) & 204 & 196 \\
B (before the discharge point) & 296 & 283 \\
$\begin{array}{l}\text { C (distance away from the } \\
\text { discharge point) }\end{array}$ & 194 & 188 \\
D (control) & 56 & 71 \\
\hline
\end{tabular}

Table 1: Total Heterotrophic Bacteria.

\begin{tabular}{|l|c|c|}
\hline Samples & $\begin{array}{c}\text { Dilution1 } \\
\mathbf{1 0}^{-3}\end{array}$ & $\begin{array}{c}\text { Dilution2 } \\
\mathbf{1 0}^{-4}\end{array}$ \\
\hline A (discharge point) & 204 & 88 \\
B (before the discharge point) & 295 & 140 \\
$\begin{array}{l}\text { C (distance away from the } \\
\text { discharge point) }\end{array}$ & 144 & 53 \\
D (control) & 41 & 22 \\
\hline
\end{tabular}

Table 2: Total Coliform Count.

\begin{tabular}{|l|c|c|}
\hline Samples & $\begin{array}{c}\text { Dilution1 } \\
\mathbf{1 0}^{-2}\end{array}$ & $\begin{array}{c}\text { Dilution2 } \\
\mathbf{1 0}^{-3}\end{array}$ \\
\hline A (discharge point) & 92 & 48 \\
$\begin{array}{l}\text { B (before the discharge } \\
\text { point) }\end{array}$ & 24 & 18 \\
$\begin{array}{l}\text { C (distance away from the } \\
\text { discharge point) }\end{array}$ & 76 & 3 \\
D (control) & 76 \\
\hline
\end{tabular}

Table 3: Total Fecal Coliform. 


\begin{tabular}{|l|c|c|}
\hline Samples & $\begin{array}{c}\text { Dilution1 } \\
\mathbf{1 0}^{-\mathbf{3}}\end{array}$ & $\begin{array}{c}\text { Dilution2 } \\
\mathbf{1 0}^{-4}\end{array}$ \\
\hline A (discharge point) & 95 & 13 \\
$\begin{array}{l}\text { B (before the discharge } \\
\text { point) }\end{array}$ & 57 & 28 \\
$\begin{array}{l}\text { C (distance away from the } \\
\text { discharge point) }\end{array}$ & 0 & 0 \\
D (control) & 0 & 0 \\
\hline
\end{tabular}

Table 4: Total Salmonella Shigella Count.

Second sampling

\begin{tabular}{|l|c|c|}
\hline Samples & $\begin{array}{c}\text { Dilution1 } \\
\mathbf{1 0}^{-6}\end{array}$ & $\begin{array}{c}\text { Dilution2 } \\
\mathbf{1 0}^{-6}\end{array}$ \\
\hline A (discharge point) & 121 & 128 \\
B (before the discharge point) & 141 & 153 \\
$\begin{array}{l}\text { C (distance away from the } \\
\text { discharge point) }\end{array}$ & 98 & 86 \\
D (control) & 61 & 48 \\
\hline
\end{tabular}

Table 5: Total Heterotrophic Bacteria.

\begin{tabular}{|l|c|c|}
\hline Samples & $\begin{array}{c}\text { Dilution1 } \\
\mathbf{1 0}^{-3}\end{array}$ & $\begin{array}{c}\text { Dilution2 } \\
\mathbf{1 0}^{-4}\end{array}$ \\
\hline A (discharge point) & 63 & 68 \\
B (before the discharge point) & 51 & 45 \\
$\begin{array}{l}\text { C (distance away from the } \\
\text { discharge point) }\end{array}$ & 38 & 32 \\
D (control) & 15 & 18 \\
\hline
\end{tabular}

Table 6: Total Coliform Count.

\begin{tabular}{|l|c|c|}
\hline Samples & $\begin{array}{c}\text { Dilution1 } \\
\mathbf{1 0}^{-\mathbf{2}}\end{array}$ & $\begin{array}{c}\text { Dilution2 } \\
\mathbf{1 0}^{-3}\end{array}$ \\
\hline A (discharge point) & 18 & 21 \\
$\begin{array}{l}\text { B (before the discharge } \\
\text { point) }\end{array}$ & 21 & 26 \\
$\begin{array}{l}\text { C (distance away from the } \\
\text { discharge point) }\end{array}$ & 15 & 19 \\
\begin{tabular}{l} 
D (control) \\
\hline
\end{tabular} & 6 & 15 \\
\hline
\end{tabular}

Table 7: Total Fecal Coliform.

\begin{tabular}{|l|c|c|}
\hline Samples & $\begin{array}{c}\text { Dilution1 } \\
\mathbf{1 0}^{-3}\end{array}$ & $\begin{array}{c}\text { Dilution2 } \\
\mathbf{1 0}^{-4}\end{array}$ \\
\hline A (discharge point) & 8 & 11 \\
B (before the discharge point) & 6 & 5 \\
$\begin{array}{l}\text { C (distance away from the } \\
\text { discharge point) }\end{array}$ & 0 & 0 \\
D (control) & 0 & 0 \\
\hline
\end{tabular}

Table 8: Total Salmonella Shigella Count.

Third sampling

\begin{tabular}{|l|c|c|}
\hline Samples & $\begin{array}{c}\text { Dilution1 } \\
\mathbf{1 0}^{-6}\end{array}$ & $\begin{array}{c}\text { Dilution2 } \\
\mathbf{1 0}^{-6}\end{array}$ \\
\hline A (discharge point) & 210 & 210 \\
B (before the discharge point) & 183 & 193 \\
$\begin{array}{l}\text { C (distance away from the } \\
\text { discharge point) }\end{array}$ & 68 & 89 \\
D (control) & 41 & 39 \\
\hline
\end{tabular}

Table 9: Total Heterotrophic Bacteria. 


\begin{tabular}{|l|c|c|}
\hline Samples & $\begin{array}{c}\text { Dilution1 } \\
\mathbf{1 0}^{-\mathbf{3}}\end{array}$ & $\begin{array}{c}\text { Dilution2 } \\
\mathbf{1 0}^{-4}\end{array}$ \\
\hline A (discharge point) & 86 & 91 \\
$\begin{array}{l}\text { B (before the discharge } \\
\text { point) }\end{array}$ & 43 & 54 \\
$\begin{array}{l}\text { C (distance away from the } \\
\text { discharge point) }\end{array}$ & 12 & 32 \\
D (control) & 11 \\
\hline
\end{tabular}

Table 10: Total Coliform Count.

\begin{tabular}{|l|c|c|}
\hline Samples & $\begin{array}{c}\text { Dilution1 } \\
\mathbf{1 0}^{-\mathbf{2}}\end{array}$ & $\begin{array}{c}\text { Dilution2 } \\
\mathbf{1 0}^{-3}\end{array}$ \\
\hline A (discharge point) & 9 & 8 \\
B (before the discharge point) & 17 & 16 \\
$\begin{array}{l}\text { C (distance away from the } \\
\text { discharge point) }\end{array}$ & 25 & 21 \\
D (control) & 9 & 8 \\
\hline
\end{tabular}

Table 11: Total Fecal Coliform.

\begin{tabular}{|l|c|c|}
\hline Samples & $\begin{array}{c}\text { Dilution1 } \\
\mathbf{1 0}^{-\mathbf{3}}\end{array}$ & $\begin{array}{c}\text { Dilution2 } \\
\mathbf{1 0}^{-4}\end{array}$ \\
\hline A (discharge point) & 11 & 9 \\
B (before the discharge point) & 13 & 2 \\
$\begin{array}{l}\text { C (distance away from the } \\
\text { discharge point) }\end{array}$ & 3 & 0 \\
D (control) & 4 & 0 \\
\hline
\end{tabular}

Table 12: Total Salmonella Shigella Count.

\section{Discussion and Conclusion}

The Total Heterotrophic bacteria, Total Coliform Counts, Total Fecal Coliform, and Total Salmonella Shigella Counts of the abattoir effluents from Eliozu abattoir during the three weeks of study as illustrated in (Tables 1 to 12) showed that microbial loads were high. These values are above the World Health Organization acceptable limits for microbial contamination for any surface sample which should not surpass $1.20 \times 10^{6} \mathrm{Cfu} / \mathrm{ml}$.

The result also revealed that the Eliozu abattoir had a higher count of the bacteria in the first week when compared to the second and third week. The low bacteria count as observed from the second and third week may be due to reduced human activities and maybe as a result of some hygienic habits by the butchers and traders. They probably had maintained good sanitary conditions in the second and third week than in the first week.

The result obtained from the studies is consistent with previous studies done by other authors such as Adesemoye., et al. [9] who noted same high count in the range of $(\mathrm{x} 107 \mathrm{Cfu} / \mathrm{g})$ bacteria from soil samples contaminated with waste water at Agege and 0jo in Lagos and also, in Sokoto abattoir, respectively in Nigeria.

A total of 18 bacteria isolates were obtained after characterization, biochemical analysis and Gram reaction and revealed the presence of 9 genera, Staphylococcus, Bacillus, Micrococcus, Salmonella, Shigella, Proteus, Serratia, Pseudomonas, Eschirichia coli. Same findings were reported by Ezeronye and Ubalua [10] who noted that isolation of Streptococcus faecalis, Escherichia coli, Staphylococcus species, Clostridium species and Salmonella species among other Rivers from Aba River due to contamination from abattoir effluents. In agreement with the study Bala [11] reported the isolation of same organisms from water corrupted by contact or association with fecal material in Jimeta-Yola, Nigeria. The presence of Escherichia coli and Pseudomonas species proves that there is human fecal pollution of these areas. The isolation of these Coliforms shows a current human contaminations of the sampling points and is of great Public Health concern [12]. The presence of Pseudomonas spp around the abattoir vicinity could be due to the presence of hydrocarbons within the abattoir. This observation supports the report by Faria and Bharathi [13] that Pseudomonas is ubiquitous in the environment and stated that they could contribute to the oxidation of hydrocarbons in the environment.

In this study, a lot of the isolates were yielding readily to Ciprofloxacin. Most of the gram negative bacteria were resistant to some of the antibiotics used and a lot of the gram positive bacteria were 
yielding readily to some of the antibiotics used. The results does not agree to the work of Lister., et al. [14] who noted that isolates showed resistance to a wide range of antimicrobial agents. The possible reason might be due to changes in time, variation of environment, and the type of contaminated effluents. When these organisms are present in waste water discharged into water bodies, they could affect the ecological balance in the water bodies. This resistance shows that there is possibility of these microorganisms to harbor plasmids with several genes coding resistance to a wide range of antibiotics. This goes a long way to show that there is high chance of spreading these pathogens and the associated resistant genes to humans and animals [15].

The Statistical analysis using Analysis of Variance (ANOVA) revealed that there is statistically significant variation between the samples for each of the parameters taken weekly from four points. The Statistical analysis implies that, THB, TCC, TFC, and, TSSC are all present in the river as an effect of pollution from the effluent discharged from the abattoir.

Conclusively, this study investigated bacterial diversity in abattoir effluent discharged into Eliozu River in Rivers State, Port Harcourt, Southern Nigeria. This study has so far shown that the sanitary and hygiene conditions of the abattoir are far from ideal and the discharged untreated effluent contains antibiotic resistant bacteria that could impact on public health.

\section{Bibliography}

1. Bhat PN and Khan BU. Goat production, Centre for Integrated Animal Husbandry, India (2009): 223-250.

2. Fearon J., et al. "Abattoir Operations, Waste generation and Management in the Tamale Metropolis: Case Study of the Tamale Slaughter house". Journal of Public Health and Epidemiology 6.1 (2014): 14-19.

3. Sangodoyin AY and Agbawhe OM. "Environmental study on surface and ground water pollutants from Abattoir Effluents". Bio-Resource Technology 41 (1992): 193-200.

4. Franco DA. "Animal disposal, the environmental, animal disease and public health related implications and assessment of options". National Renderers Association, Canada (2002): 120-122.
5. Mohammed S and Musa JJ. "Impact of abattoir effluent on river Landzu, Bida, Nigeria”. Journal of Chemical, Biological and Physical Sciences 2.1 (2012): 132-136.

6. Bello YO and Oyedemi DTA. "Impact of abattoir activities and management in residential neighborhoods, Nigeria". Journal of Social Science 19 (2009): 121-127.

7. Bull MA., et al. "The treatment of Waste Water from the Meat Industry". Environmental Technology 3 (1982): 117-126.

8. Coker AO., et al. "Abattoir waste water quality in Southwestern Nigeria". Proceedings of the 27th Water, Engineering and development center (WEDC) conference, Lusaka, Zambia. Loughborough University press, United Kingdom 8 (2001): 329-331.

9. Adesemoye AO., et al. "Microbial content of abattoir waste water and its contaminated soil in Lagos, Nigeria". African Journal of Biotechnology 5.20 (2006): 1963-1968.

10. Ezeronye OU and Ubqalua AO. "Studies in the effect of abattoir and industrial efflents on the heavy metals and microbial quality of Aba river in Nigeria”. African Journal of Biotechnology 4.3 (2005): 266-272.

11. Bala JD. "Occurrence on faecal coliforms in the water sources in Jimeta-Yola, Nigeria". Journal of Environmental Sciences 10.2 (2006): 64-69.

12. Ezeama CF and Nwamkpa F. "Studies on the Longitudinal profile of the bacteriological quality of Aba river, Nigeria". Global Journal of Pure and Applied Sciences 8.4 (2002): 469-73.

13. Faria D and Bharathi L. "Marine and Estuarine Methylotrophs: Their abundance, activity and identity". Current Science 90.7 (2006): 984-989.

14. Lister PD., et al. "Antibacterial-resistant Psedomonasaeruginosa: Clinical impact and complex regulation of chromosomally encoded resistant mechainms". Clinical Microbiology Review 22.4 (2009): 582-610.

15. Singh VP and Neelam S. "A survey report on Impact of Abattoir Activities Management on environments". Indian Journal of Veterinary 6 (2011): 973-978.

Volume 4 Issue 11 November 2021 (C) All rights are reserved by CJ Ugboma, et al. 